MaPan : Jurnal Matematika dan Pembelajaran

p-ISSN: 2354-6883 ; e-ISSN: 2581-172X

Volume 5, No 2, December 2017 (251-258)

DOI: https://doi.org/10.24252/mapan.v5n2a7

\title{
HUBUNGAN KECERDASAN EMOSI DENGAN PRESTASI BELAJAR PADA MATA KULIAH MICROTEACHING MAHASISWA PENDIDIKAN MATEMATIKA UNIVERSITAS SULAWESI BARAT
}

\author{
Nenny Indrawati ${ }^{1}$ ), Nurmiati ${ }^{2}$ ) \\ 1,2Universitas Sulawesi Barat \\ 1,2Kampus: Jalan Prof. Dr. Baharuddin Lopa, SH, Talumung, Majene, Sulawesi Barat \\ E-mail: nennyindrawati1412@gmail.com ${ }^{1)}$, nurmialbugisi@gmail.com ${ }^{2}$ )
}

Submitted: 04-10-2017, Revised: 15-10-2017, Accepted: 31-10-2017

\begin{abstract}
Abstrak:
Penelitian ini adalah penelitian korelasional yang bertujuan untuk menganalisis hubungan kecerdasan emosi dengan prestasi belajar mahasiswa pendidikan matematika semester VIII pada mata kuliah Microteaching di Universitas Sulawesi Barat, menganalisis hubungan dengan prestasi belajar mahasiswa pendidikan matematika semester VIII pada mata kuliah Microteaching di Universitas Sulawesi Barat, dan menganalisis hubungan kecerdasan emosi dengan prestasi belajar mahasiswa pendidikan matematika semester VIII pada mata kuliah Microteaching di Universitas Sulawesi Barat. Metode yang digunakan adalah metode penelitian korelasi dengan observasional analitik dengan pendekatan cross sectional. Objek dari penelitian ini adalah seluruh mahasiswa pendidikan matematika semester VIII berjumlah 31 orang. Teknik analisis data dari penelitian ini adalah analisis korelasi sederhana, dan analisis regresi linear sederhana. Hasil penelitian ini menunjukkan (1) terdapat hubungan positif dan signifikan antara kecerdasan emosi dan prestasi belajar sebesar 0,594, (2) persamaan regresi yang terbentuk adalah $\mathrm{Y}=36,954+0,568 \mathrm{X}$.
\end{abstract}

Kata Kunci: Kecerdasan Emosi, Prestasi Belajar

\section{THE CORRELATOIN OF EMOTIONAL QUOTIENT AND LEARNING ACHIEVEMENT OF MATHEMATICS EDUCATION STUDENTS TOWARDS MICROTEACHING SUBJECT AT WEST SULAWESI UNIVERSITY}

\begin{abstract}
:
This correlational research aims to analyze the correlation of emotional quotient and learning achievement of mathematics education of students semester VIII towards microteaching subject at West Sulawesi University. The research applied correlational research method with observational analysis and cros sectional approach. The research object is 31 students of mathematics education semester VIII. The technique of data analysis is simple correlational analysis and simple regressive analysis. This research shows that: (1) there is a positive and significant correlation between emotional quotient and learning achievement 0,594, (2) Regression equation is $Y=36,954+0,568 X$.
\end{abstract}

Keywords: Emotional Quotient, Learning Achievement 
How to Cite: Indrawati, N., \& Nurmiati. (2017). Hubungan Kecerdasan Emosi dengan Prestasi Belajar Pada Mata Kuliah Microteaching Mahasiswa Pendidikan Matematika Universitas Sulawesi Barat. MaPan : Jurnal Matematika dan Pembelajaran, 5(2), 251-258.

$\mathrm{P}$ endidikan adalah faktor terpenting dalam peningkatan kualitas sumber daya manusia suatu bangsa. Oleh karena itu upaya untuk menciptakan sumber daya manusia yang berkualitas harus berawal dari proses pendidikan yang berkualitas pula. Hal ini dapat dikembangkan dengan memperhatikan setiap aspek belajar, baik aspek kognitif, afektif, dan psikomotorik (Djamariah dan Aswan, 2006). Pendidikan harus mampu menyeimbangkan antara kecerdasan intelektual dengan kecerdasan emosi, termasuk dalam proses pendidikan di tingkat perguruan tinggi.

Fakta di lapangan menunjukkan bahwa IQ hanya mempunyai peran sekitar 20\% dalam menentukan prestasi individu, 80\% sisanya ditentukan oleh faktor-faktor lain termasuk kecerdasan emosi. Hal tersebut selaras dengan pendapat Gottman (2008), bahwa siswa yang memiliki kecerdasan emosi yang tinggi akan lebih terampil dalam menenangkan diri sendiri, terampil dalam memusatkan perhatian, memiliki hubungan yang lebih baik dengan orang lain, lebih cakap memahami orang, memiliki persahabatan yang baik dengan anak lain, serta memiliki prestasi belajar yang lebih baik.

Kecerdasan emosional merupakan faktor penting yang mempengaruhi hasil belajar. Jika kecerdasan emosi baik maka akan sangat meningkatkan hasil belajar (Mustaqim, 2012). Kemampuan akademis yang tinggi ditunjang dengan kecerdasan emosi yang baik akan membuka banyak kesuksesan bagi seseorang, baik pada dunia kerja, pribadi, maupun proses belajar mengajar.

Hasil penelitian-penelitian psikologi kontemporer menunjukkan bahwa selain ditentukan oleh IQ, ternyata belajar dan prestasi juga ditentukan oleh emotional intelligence atau kecerdasan emosi. Hal tersebut diperkuat dengan pendapat Uno (2008) yang juga menyatakan bahwa kecerdasan emosi diperlukan oleh siswa untuk berprestasi.

Berdasarkan fakta di lapangan, di mana peneliti sebagai pengampu mata kuliah microteaching untuk mahasiswa semester VI tahun akademik 2015-2016, dari hasil evaluasi selama satu semester diperoleh informasi bahwa sebagian besar mahasiswa masih kurang siap untuk belajar mengajar di depan kelas (microteaching). Mahasiswa cenderung terlihat gugup, hilang konsentrasi, 
kurang percaya diri dan tidak mampu untuk menjalankan praktek mengajar dengan baik.

Berdasarkan uraian di atas dan berdasarkan toeri yang dikemukakan oleh Goleman (2015) yang menyatakan bahwa EQ memberikan pengaruh terhadap keberhasilan seseorang, maka dapat diasumsikan bahwa kecerdasan emosi dan kesiapan belajar merupakan variabel yang dapat mempengaruhi prestasi belajar mahasiswa. Penelitian ini sangat penting untuk dilakukan karena selama ini mahasiswa cenderung mengikuti perkuliahan tanpa adanya kesiapan baik dari aspek intelektual maupun emosional dan hal itu berpengaruh pada prestasi belajarnya. Dari penellitian ini pula di harapkan dosen dapat menentukan strategi yang tepat untuk mengembangkan dan meningkatkan kecerdasan emosi dan kesiapan belajar mahasiswanya. Oleh karena itu penulis tertarik untuk melakukan penelitian mengenai hubungan kecerdasan emosi dan kesiapan belajar dengan prestasi belajar pada mata kuliah microteaching mahasiswa pendidikan matematika Universitas Sulawesi Barat.

\section{METODE PENELITIAN}

Jenis penelitian yang digunakan adalah observasi analitik dengan pendekatan cross sectional. Data digunakan adalah data primer yang diperoleh dari seluruh mahasiswa pendidikan matematika Universitas Sulawesi Barat semester VIII tahun ajaran 2016-2017 sebanyak 31 orang melalui pengisian angket kecerdasan emosi dan angket kesiapan belajar dengan menggunakan model rating scale sebagai metode penskoran skala yang terdiri dari empat alternatif jawaban.

Proses analisis data dilakukan dalam dua tahap yaitu pengujian prasyarat dan pengujian hipotesis. Pengujian prasyarat dengan menggunakan uji normalitas dan uji linearitas. Sedangkan pengujian hipotesis sebagai berikut, yaitu:

a. Uji Hipotesis

Penghitungan korelasi kecerdasan emosi $\left(\mathrm{X}_{1}\right)$ dan prestasi belajar $(\mathrm{Y})$ dengan rumus:

$$
R_{\left(X_{1} Y\right)}=\frac{\sum X_{1} Y}{\sqrt{\left(\sum X_{1}^{2}\right)\left(\sum Y^{2}\right)}}
$$

Dengan: $\mathrm{R}=$ Koefisien Korelasi, $\mathrm{X}=$ Kecerdasan Emosi, $\mathrm{Y}=$ Prestasi Belajar 
$\mathrm{H}_{0}$ : Tidak ada hubungan antara kecerdasan emosi dengan prestasi belajar mahasiswa.

$\mathrm{H}_{1}$ : Ada hubungan positif antara kecerdasan emosi dengan prestasi belajar mahasiswa

Bila $\mathrm{r}_{\text {hitung }}<\mathrm{r}_{\text {tabel }}$ maka $\mathrm{H}_{0}$ diterima dan $\mathrm{H}_{1}$ di tolak. Begitupun sebaliknya jika $\mathrm{r}_{\text {tabel }}<\mathrm{r}_{\text {hitung }}$ maka $\mathrm{H}_{0}$ ditolak dan $\mathrm{H}_{1}$ diterima. Begitupun sebaliknya jika $\mathrm{r}_{\text {tabel }}<$ $\mathrm{r}_{\text {hitung }}$ maka $\mathrm{H}_{0}$ ditolak dan $\mathrm{H}_{1}$ diterima.

Analisis regresi linear sederhana digunakan jika peneliti bermaksud untuk meramalkan besar hubungan antara variabel $X$ terhadap variabel $Y$, dengan persamaan:

$$
Y=a+b X
$$

dengan: $\mathrm{Y}=$ Prestasi Belajar, $\mathrm{X}=$ Kecerdasan Emosi, $\mathrm{a}=$ Konstanta Regresi $\mathrm{b}=$ Slope

\section{HASIL PENELITIAN DAN PEMBAHASAN}

\section{Hasil Penelitian}

Data yang diperoleh melalui angket yang diberikan kepada subjek penelitian selanjutnya dianalisis dan diinterpretasikan.

a. Deskripsi Data

1. Variabel Kecerdasan Emosi $\left(X_{1}\right)$

Deskripsi data di bawah ini menunjukkan distribusi kecerdasan emosi mahasiswa semester VIII pada mata kuliah Microteaching, diberikan pada tabel berikut:

Tabel 1. Distribusi Data Kecerdasan Emosi

\begin{tabular}{ccc}
\hline Kecerdasan Emosi & Frekuensi & Persentase \\
\hline Sangat Baik & 19 & 61,29 \\
Baik & 12 & 38,71 \\
Jumlah & 31 & 100,00 \\
\hline
\end{tabular}

Berdasarkan hasil distribusi responden tentang kecerdasan emosi diketahui bahwa $61,29 \%$ atau 19 orang mempunyai keceradasan emosi ada kategori sangat baik dan $38,71 \%$ atau 12 orang mempunyai kecerdasan emosi ada kategori baik, sehingga dari hasil peneilitian diketahui bahwa sebagian besar kecerdasan emosi mahasiswa berada pada kategori sangat baik. 
2. Variabel Prestasi Belajar $(\mathrm{Y})$

Deskripsi data di bawah ini menunjukkan distribusi prestasi belajar mahasiswa semester VIII pada mata kuliah Microteaching, diberikan pada tabel berikut:

Tabel 2. Distribusi Data Prestasi Belajar

\begin{tabular}{ccc}
\hline Kesiapan Belajar & Frekuensi & Persentase \\
\hline Baik Sekali & 10 & 32,26 \\
Baik & 16 & 51,61 \\
Cukup & 5 & 16,13 \\
Jumlah & 31 & 100,00 \\
\hline
\end{tabular}

Berdasarkan hasil distribusi responden tentang prestasi belajar diketahui bahwa $32,26 \%$ atau 10 orang mempunyai prestasi belajar baik sekali, 51,61\% atau 16 orang mempunyai prestasi belajar baik, dan $16,13 \%$ atau 5 orang mempunyai prestasi belajar cukup, sehingga hasil peneilitian diketahui bahwa sebagian besar prestasi belajar mahasiswa berada pada kategori baik.

b. Pengujian Analisis Prasyarat

Sebelum dilakukan uji hipotesis, maka terlebih dahulu dilakukan uji analisis prasyarat sebagai berikut:

\section{Uji Normalitas}

Berdasarkan hasil uji normalitas dengan menggunakan analisis SPSS dengan teknik Kolmogorov-Smirnov maka diperoleh hasil masing-masing variabel sebagai berikut:

Tabel 3. Hasil Analisis Uji Normalitas

\begin{tabular}{ccccc}
\hline No. & Variabel & Sig. & a & Keterangan \\
\hline 1 & $\mathrm{X}$ & 0,833 & 0,05 & Normal \\
2 & $\mathrm{Y}$ & 0,556 & 0,05 & Normal \\
\hline
\end{tabular}

Berdasarkan tabel 3, dapat dilihat bahwa masing-masing variabel yaitu kecerdasan emosi $(\mathrm{X})$, dan prestasi belajar (Y) berdasarkan hasil uji 
Kolmogorov-Smirnov memiliki nilai $>$ 0,05 sehingga dapat dikatakan distribusi sampel adalah normal.

\section{Uji Linearitas}

Berdasarkan hasil uji linearitas diperoleh hasil dari hubungan antara variabel kecerdasan emosi dengan variabel prestasi belajar dan variabel kesiapan belajar dengan variabel prestasi belajar sebagai berikut:

Tabel 4. Hasil Analisis Uji Linearitas

\begin{tabular}{ccccc}
\hline No. & Variabel & Sig. & $\alpha$ & Keterangan \\
\hline 1 & Y atas X & 0,08 & 0,05 & Linear \\
\hline
\end{tabular}

Berdasarkan tabel 4, diperoleh nilai signifikansi prestasi belajar terhadap kecerdasan emosi ( $\mathrm{Y}$ atas $\mathrm{X}$ ) sebesar 0,08 > 0,05, Dari nilai siginfikansi tersebut dapat disimpulkan bahwa terdapat hubugan linear secara signifikan antara variabel kecerdasan emosi $(X)$ terhadap prestasi belajar mahasiswa $(Y)$.

\section{c. Pengujian Hipotesis Penelitian}

Setelah uji prasyarat terpenuhi, maka selanjutnya dilakukan pengujian hipotesis. Penelitian ini memperoleh data yang menunjukkan bahwa koefisien korelasi ( $\mathrm{R}_{\text {hitung }}$ ) kecerdasan emosi $\left(\mathrm{X}_{1}\right)$ dengan prestasi belajar $(\mathrm{Y})$ sebesar 0,594. Selanjutnya dilakukan uji signifikansi hubungan dengan menggunakan statistik

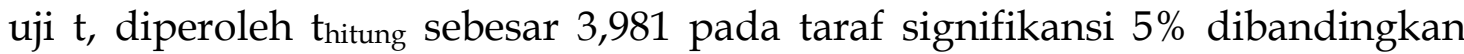
dengan $t_{\text {tabel }}(d k=29)$ sebesar 1,699 . Karena thitung $>t_{\text {tabel }}$ maka dapat dinyatakan bahwa $\mathrm{H}_{0}$ ditolak dan $\mathrm{H}_{1}$ diterima yang menyatakan ada hubungan positif antara kecerdasan emosi terhadap prestasi belajar. Ini berarti semakin baik kecerdasan emosi mahasiswa maka semakin baik pula prestasi belajarnya. Besar pengaruh kecerdasan emosi $(\mathrm{X})$ dengan prestasi belajar $(\mathrm{Y})$ dilihat berdasarkan sumbangan efektifnya yaitu sebesar $35,3 \%$.

Tabel 5. Hasil Analisis Uji Regresi Linear Sederhana

\begin{tabular}{|c|c|c|c|c|c|c|}
\hline \multirow{2}{*}{\multicolumn{2}{|c|}{ Model }} & \multicolumn{2}{|c|}{ Unstandardized Coefficients } & \multirow{2}{*}{$\begin{array}{c}\text { Standardized } \\
\text { Coefficients } \\
\text { Beta } \\
\end{array}$} & \multirow[b]{2}{*}{$t$} & \multirow[b]{2}{*}{ Sig. } \\
\hline & & $B$ & Std. Error & & & \\
\hline \multirow[t]{2}{*}{1} & (Constant) & 36.954 & 9.652 & & 3.828 & .001 \\
\hline & Kecerdasan Emosi & .568 & .143 & .594 & 3.981 & .000 \\
\hline
\end{tabular}

a. Dependent Variable: Nilai 
Bentuk persamaan regresi yang diperoleh dari analisis hipotesis adalah $Y=36,954+0,568 \mathrm{X}$. Bentuk regresi ini menyatakan bahwa setiap kenaikan satu satuan kecerdasan emosi maka prestasi belajar meningkat sebesar 0,568.

\section{Pembahasan}

Penelitian ini dilakukan untuk mengetahui hubungan antara kecerdasan emosi dan kesiapan belajar terhadap prestasi belajar. Berdasarkan data yang telah dikumpulkan dan dianalaisis maka diberikan pembahasan bahwa Penelitian ini memperoleh data yang menunjukkan bahwa koefisien korelasi kecerdasan emosi $\left(\mathrm{X}_{1}\right)$ dengan prestasi belajar $(\mathrm{Y})$ sebesar 0,594. Selanjutnya dilakukan uji signifikansi hubungan dengan menggunakan statistik uji $t$, diperoleh $t_{\text {hitung }}$ sebesar 3,981 pada taraf signifikansi 5\% dibandingkan dengan $t_{\text {tabel }}(d k=29)$ sebesar 1,699 . Karena thitung $>t_{\text {tabel }}$ maka dapat dinyatakan bahwa $\mathrm{H}_{0}$ ditolak dan $\mathrm{H}_{1}$ diterima yang menyatakan ada hubungan positif antara kecerdasan emosi terhadap prestasi belajar. Ini berarti semakin baik kecerdasan emosi mahasiswa maka semakin baik pula prestasi belajarnya. Besar pengaruh kecerdasan emosi $\left(\mathrm{X}_{1}\right)$ dengan prestasi belajar $(\mathrm{Y})$ dilihat berdasarkan sumbangan efektifnya yaitu sebesar 35,3\%.

Kecerdasan emosi merupakan salah satu factor penting yang mendukung keberhasilan seseorang. Hal ini sejalan hasil penelitian yang menyatakan bahwa $20 \%$ keberhasilan sesorang ditentukan oleh faktor IQ, selebihnya 80\% ditentukan oleh EQ individu (dalam hal ini kecerdasan emosi). Kecerdasan emosi pula mempengaruhi kecakapan komunikasi yang tentu saja akan turut memberikan kontribusi bagi masa depan seseorang.

Hasil penelitian ini sejalan dengan hasil penelitian Putri (2011) yang menyatakan terdapat hubungan positif antara kecerdasan emosi dengan prestasi belajar mahasiswa.

\section{SIMPULAN}

Berdasarkan hasil analisis data yang telah dibahas, maka diperoleh kesimpulan sebagai berikut: terdapat hubungan yang positif dan signifikan antara kecerdasan emosi dengan prestasi belajar pada mata kuliah microteaching mahasiswa semester VIII program studi pendidikan matematika Universitas Sulawesi Barat. Hal ini berarti semakin baik kecerdasan emosi yang dimiliki mahasiswa maka akan semakin baik pula prestasi belajarnya. 


\section{DAFTAR PUSTAKA}

Djamariah, B. S. \& Aswan, Z. (2006). Strategi belajar mengajar. PT Rineka Cipta.

Goleman, D. (2015). Emotional intelligence. (Diterjemahkan: T. Hermaya). PT Gramedia Pustaka Utama.

Gottman, Joan, John \& Claire D. (2008). Mengembangkan kecerdasan emosional anak. (Penerjemah: T. Hermaya). Jakarta: PT Gramedia Pustaka Utama

Mustaqim. (2012). Psikologi pendidikan. Pustaka Pelajar.

Putri. N. K. (2011). Hubungan kecerdasan emosi dan kesiapan belajar dengan prestasi belajar pada mata kuliah ASKEB IBU I mahasiswa semester II di AKBID Mitra Husada Karanganyar. Thesis. Universitas Sebelas Maret. Surakarta.

Uno H. B. (2008). Orientasi baru dalam psikologi pembelajaran. PT. Bumi Aksara. 